\title{
Finding of Hard and Soft Territory in Rental Low-Cost Apartment by Using Grounded Theory Method
}

\author{
Fermanto Lianto ( $\nabla$ fermantol@ft.untar.ac.id ) \\ Universitas Tarumanagara https://orcid.org/0000-0002-0249-4660 \\ Lilianny Sigit Arifin \\ Universitas Kristen Petra \\ Y. Basuki Dwisusanto \\ Universitas Katholik Parahyangan https://orcid.org/0000-0003-2686-5048

\section{Rudy Trisno} \\ Universitas Tarumanagara https://orcid.org/0000-0001-7357-1291
}

\section{Research Article}

Keywords: Guyub Culture (Being close-knit), Grounded Theory, Hard \& Soft Territory, Share corridor, Tangible and Intangible

Posted Date: March 1st, 2021

DOl: https://doi.org/10.21203/rs.3.rs-259935/v1

License: () (7) This work is licensed under a Creative Commons Attribution 4.0 International License. Read Full License 


\section{Abstract}

Sharing a corridor space in a rusunawa could form patterns of adaptation and exemplify the phenomenon of territorial mastery. This research aims to understand the form of this mastery as perceived by the occupants using the Grounded Theory method. The results show a theory of territorial mastery that can be developed from the findings in the field is a new theory of territorial characteristics, based on hard and soft territory. The hard territory is territorial control that is tangible or intangible, fixed or unchanged, and firm, whose existence is clear in a space that can be seen, occupied or controlled and maintained, and recognized by other residents. On the other hand, the soft territory is territorial control that is tangible and intangible, and which allows for flexible and soft shifts because it is an expression of the family and cultural emotions of guyub, so that mastery of the soft territory occurs not only because of tolerance, but also because of the prioritization of the feeling of kinship in living under one roof, and the harmonization of guyub relationships amongst people in a community

\section{Introduction}

The corridor in a rusunawa (rental low-cost apartment) is intended for public circulation. However, we often encounter the residents using the corridor for personal items and other activities. This phenomenon shows that the corridor is not just a means of circulation but has developed according to the needs of household characteristics. Some conditions have been found which have caused adjustments to or changes in the behavior of the rusuna (low-cost apartment), including aspects of behavior, social conditions, and physical occupancy, especially relating to ownership boundaries (territory). The socio-economic conditions of lowincome communities form distinctive and complex behavioral patterns and values. Daily habits and ways of life in interacting, gathering, and living as neighbors can affect the territorial understanding of the rusunawa residents. This is also caused by the demographic aspects of the rusunawa, which is inhabited by various age groups, from babies to elders, with their respective backgrounds and characters, and different activities 24 hours a day.

The small size of a living unit (sarusun) in a rusunawa and the culture of the low-income communities who used to live in an urban kampung (Kamil, 2015, p. 148) influence the changes in behavior, character, and dwelling culture in the rusunawa, and the people are thought to have different territorial understandings. The problems in the rusunawa are therefore feasible for in-depth research to establish the actual conditions of phenomena that occur in the field and the factors that cause them, and to provide input theory about the territories that characterize the life of the rusunawa in Indonesia.

Based on the above phenomena, by building new substantive theories, this research formulates aspects related to the form of territorial mastery in the context of humans as users in the community, as well as theorizing of the occupants' understanding of territory because of the phenomenon of territorial mastery.

\section{Materials And Methods}

\subsection{Rusunawa Bumi Cengkareng Indah}

The research was conducted at block Seruni 5, Rusunawa Bumi Cengkareng Indah (Perumnas Cengkareng), Cengkareng, West Jakarta, 11730, Indonesia. The ground floor of block Seruni 5 functions as a Rukun Warga(RW), comprising a neighborhood council office, electricity rooms, motorbike parking, toilets, and business premises such as games stations, beauty salons, food stalls, studios, etc. (see Figure 1). About the occupancy function on floors one to four, each floor consists of 12 sarusun (apartment unit) units, with one access in and out which is in the middle part of the building and which also functions as a vertical (ladder) circulation path. The type of corridor in this block is therefore a dead-end corridor on the left and right-hand sides of the building.

\subsection{Methodology}

The Grounded Theory (GT) methodology was invented by Barney Glaser and Anselm Strauss (Classic GT) (Glaser, 1994; Setyowati, 2010), which was later developed by Juliet Corbin (Straussian GT) (Goulding, 2002; Pryor, 2009; Strauss \& Corbin, 2015). Straussian GT was popular for research in social science and well-known as the basic social. Next, Kathy Charmaz (Charmaz, 2006; Samuel, A., 2011), once modified the GT methodology to decrease its rigidness and modified it to be easily combined with other disciplines (Constructivist GT) became more flexible.

Page $2 / 20$ 
The GT is useful in architectural research because it generates a new substantive theory/concept, based on a phenomenon that happened in daily life (the theory is grounded by data) (Lianto, 2019). The GT facilitates researchers the ability to create theory through data retrieved from the field (Castillo, 2018). GT plays an important role in developing and building theory from data (Khan, 2014). The GT method is based on data collection on the ongoing behavior (life history) of residents who experience a phenomenon by giving them the freedom to express their feelings without any intervention or assessment from the researcher (Strauss \& Corbin, 1990; Creswell, 1998). This is done to observe the process, to capture causal aspects, based on occupants' behavior, through observation, depiction, and in-depth interviews, with structured analysis. In the GT approach, concept, hypothesis, and theory shall be formulated from empirical data, transforming phenomena to a conceptual-theoretical level. An operational step suggested for an ideal GT methodology is presented as follows (see Figure 2):

This research aims to establish and understand the needs of residents that have not been previously revealed and give them great freedom to convey the impressions and feelings they experience in their daily lives in the rusunawa. From the results of the life story analysis, understanding of territorial mastery from the occupants' point of view will be elaborated, categorized, and formulated. The following step is through inductive analysis to build substantive theories based on the facts from the field (Strauss \& Corbin, 1990; Daymond \& Holloway, 2008; Glaser \& Strauss, 1967) about the understanding of territory of the occupants', due to the phenomenon of territorial mastery and the dominant factors influencing it.

\subsection{Territorial Framework}

Every human being as an individual wants to claim and defend his territory (defensible territory) in various ways (through signs, or physical or non-physical boundaries, etc.), so as not to be disturbed by others (Newman, 1972 b; Holahan, Environmental Psychology, 1982; Haryadi \& Setiawan, Arsitektur Lingkungan dan Perilaku, 2010, p. 38; Lyman \& Scott, Territoriality: A Neglected Sociological Dimension, 1967; Sommer \& Becker, 1969; Aurora, Territory and Subjectivity: The Philosophical Nomadism of Deleuze and Canetti, 2014, p. 12). There are body territories, which include the space encompassed by the human body and the anatomical space of the body (Lyman \& Scott, 1967, p. 241). Humans, as social beings, also want to interact with other humans in their communities to provide wider territory and to maintain it together in a responsible way (with a sense of community) in everyday life (Altman, 1975; Sommer, 1969). There is a need to recognize that collective strategy sharing of space may be suitable for certain activities, but not for others (Yatmo \& Atmodiwirjo, 2013).

Building dwelling is the process of linkages between humans (as individual beings) with their place, environment, and neighboring life as social beings (Heidegger, 1971, p. 147; Schulz, 1988, pp. 17-38; Salura, 2001, p. 55), so it is inseparable from the territorial elements related to ownership boundaries (both tangible and intangible) that need to be protected and maintained to avoid conflicts of interest and struggle or control over public/shared space or facilities. Territoriality in the rusunawa is formed by residents' needs, behaviors, characteristics, and socio-cultural conditions, and is not individually constructed, but compromised (Lianto \& Dwisusanto, 2015, p. 226). Togetherness and social interaction-psychological needs, with no reference to territorial boundaries, characterize living in rusunami/owned low-cost apartments (Lianto, et al., 2017, p. 404).

\subsection{Previous Research on Territorial Issues}

\subsubsection{Public Space Territory}

This research is using a qualitative method with a rationalistic, scientific approach, which found that public territories are home yards, terrace houses, and additional buildings such as stalls, stalls, and toilets in yards. The house becomes the basis for the classification of spaces/places in the homes of residents in the Tondano Java village (Soukotta, et al., 2014).

Other research is using a descriptive method, in-depth and systematic observation, found that territories are formed in users of groups (communities) with the same settings and can be controlled because of mutual respect, maintain order, not invade against other groups (Supriyono, 2014).

The territorial research of the Malang Square area as a spatial transformation due to the development of time is using qualitative research with synchronous-diachronic analysis to compare the current and past conditions of the square, to map spatial. Territorial 
transformations are divided into a change of physical and non-physical elements, including the function of activities that constitute a unified territory marker that forms the image of the region (Sari, 2013).

\subsubsection{Classification in Territories}

Research related to the classification of public territorial spaces, which found that the classification of spaces/places in people's homes in Tondano Java village was based on public territory (Soukotta, et al., 2014).

Other research on the study of market territoriality and behavior, using the method of place centered mapping, interviews, and observations, found that changes in the value of territories were carried out by most traders. Territories that have initially been public, such as corridor space, become secondary territories. The primary territory of the stall, due to inadequate space requirements, was transformed by traders by taking part in the corridor space in front of the stand to become a secondary territory. To limit the territory, they used merchandise as a boundary. This omission seems to be legal, and there is no action from the market manager. The shift in the value of this territory becomes a necessity because there is no change from day to day. It is as if the traders are not aware that due to their actions, visitors are disadvantaged. For this reason, awareness of the rights of others is the key to the comfort of doing activities in public spaces (Murti, 2012).

\subsubsection{Territory as an Approach}

Research on spatial flexibility in the Sinoman and Biyada traditions with a territorial approach and qualitative descriptive methods found that the flexibility of space in the Sinoman and Biyada traditions in Karang Ampel Hamlet Malang is due to the characteristics and function of space change flexibly from Day-3 to Day-0. Spatial flexibility occurs, resulting in an expansion of territory to the surrounding environment. Despite the invasion of territories into neighboring areas, residents did not object to the situation. This is because socially, citizens are aware and ready to help in all things, especially for 3 (three) big things, namely death, birth, and celebration. Besides socially, physically, it can also be observed that the expansion of territories that invade neighboring neighbors does not necessarily invade their private space, i.e., rooms so that there is still room for the neighbor in his own house (Putri, et al., 2012).

Research into territorial control mechanisms in RSS (Rumah Susun Sederhana/Low-Cost Apartment), tracing the potential territoriality approach to explain the symptoms of changes in the physical setting of RSS by its inhabitants. With a descriptiveexplanatory approach, finding the purpose of changing the physical layout of the house and page as a manifestation of the mechanism of territorial defenses most frequently carried out by the respondent/occupant, then followed by the purpose of changing the physical layout of the house and yard as a form of mechanism to fulfill the needs of its utilization and the least done by respondents is the purpose of changing the physical layout of the house and yard as a form of personalization mechanism of the territory (Sastrohutomo \& Sudarma, 2007).

\subsubsection{Gender as a Territorial Limit}

Research on gender in the territory is using a descriptive method of analysis, found that territoriality in humans has a higher function than just maintaining life. Territoriality is not only a manifestation of privacy but has social and communication services. One's territory towards others is a gender territory. Gender restrictions themselves also refer to social and cultural contexts. The gender dominance of women compared to men is caused by femininity (the nature of women that has limited both in terms of psychology, physical, etc.) (Fatimah, 2010/2011).

\subsubsection{Territoriality in Traditional Context}

Traditional settlement research concludes that there has not been a development of spatial theory about the territorial meaning that addresses specific contexts related to cultural and social interactions that have unique characteristics regarding cultural systems, social systems, and physical culture (Zubaidi, et al., 2013).

Page $4 / 20$ 
Research of modern society by examining in terms of social and psychological aspects concluded that as a culture of residence. Apartments indeed take a long time and are consistent with continuing to be developed as a new tradition in human life, especially in developing countries like Indonesia, which already has a long-standing tradition that is firmly rooted in the community (Bahri, 2005).

\subsubsection{Territorial Characteristics}

The spatial territoriality characteristics in dense settlements in the Klitren Lor village were seen from the spatial function and the actions that were generated, community agreements, physical environmental factors and social factors culture, land status and the number of activities, and others. Which, after traced form community territories based on Primary territory, secondary territory, and public territory (Burhanuddin, 2010).

\subsubsection{Territoriality is Part of Everyday Life}

Territorial is a type of attachment to excessive places; it was developed directly from the sense of attachment of youth to their environment. Their place of residence or the area around them is a place they feel owned, and vice versa, those places belong to them, and they are ready to defend it. Territorial is a part of life in places formed by the routine use of streets by young people as a place to gather and relax (Kintrea, et al., 2010).

\subsubsection{Territorial Issues with Low-Cost Apartment Objects}

The territorial behavior and personalization were useful in allocating space near the home, for example, to create boundaries or semi-private spaces intended to control access both visually and physically (Aziz \& Ahmad, 2009). Other research is about the territorial control mechanism in the low-cost apartment (Sastrohutomo \& Sudarma, 2007), which uses the territory as an approach, and research on flats as a form of culture of modern society (Bahri, 2005).

The concept of territorial behavior consists of a group of street vendors, shop owners, and parking attendants that cause disturbance or change in the territoriality of other groups. The territorial behavior of the shop owner group in response to efforts to maintain or clarify the limits of their territory of authority from other parties that are perceived as a threat (Kurniadi, et al., 2012).

\section{Results And Discussion}

Territories are formed from elements that 'define space' through vertical edges, and lower horizontal (ground surface) and upper horizontal (overhang) forms. The results of field observations and interviews using the GT method show that the existence of territory can be seen directly (obtained from observations and mapping), is clear and tangible (physical), or indirect, unclear and unreal, but its existence (in non-physical) can be felt and recognized by other residents (based on interviews with residents). Based on the categorization of territorial mastery, elements, and forms of it undertaken by residents, both tangibly and intangibly, to establish the territorial understanding of the occupants are identified.

\subsection{Patterns of Territorial Mastery}

From the results in the field, it was shown that the occupants placed chairs to receive guests in the front hall of the sarusun unit. Sitting relaxed while ngerumpi (chatting) and socializing in the corridor is a basic need that is felt to be necessary, such as the function of the terrace at home. Usually, male guests are received in the corridor, while female guests or family/close relatives and neighbors are received in the sarusun unit. In certain conditions, the corridor also functions as a place to stay or for guests to sleep, with other residents understanding the situation. This demonstrates the importance of the function of the terrace for the activity of receiving guests, chatting, and staying/sleeping, thus forming a semi-private territory in the semi-public corridor.

The position of the sarusun unit also determines the pattern of mastery of the corridor, which generally occurs in (1a), the corridor in front of the sarusun unit (see Figure 3 and Figure 4), and (2), the plant area. In general, residents use the corridor in front of each

Page $5 / 20$ 
sarusun unit to keep items, while the plant area is utilized if residents do not like plants or existing plants are not well maintained and eventually die, so then the area is used as a place to put items or is left empty (see Figure 3 and Figure 5). The pattern of territorial mastery is generally limited to the area in front of the sarusun unit, the plant area, and no acts of aggression occur which lead to the contested territory, as the inhabitants of Seruni 5 generally have mutual respect and understanding as a result of living under one roof or in one building over a fairly long period, so the factors of togetherness and guyub (being close-knit) are dominant in territorial understanding.

The next mastery pattern is (1b), the corner position (see Figure 3 and Figure 6 ), and (1c), the corner position of the building (see Figure 3 and Figure 7). The corner position is a favorite place to live in, as the stairs are only in the middle of the building, so there are dead-ends at both ends of the building (Corner of the Building). This is due to the wider corridor size that residents can use to keep items, or which serves as a living room. Also, the landing, (3), is used as a place to keeps items (see Figure 3). The position or location of the sarusun unit also influences the pattern of formation of territorial mastery.

\subsection{Residents' Understanding of Territories}

Rusunawa block Seruni 5 is intentionally targeted at young couples who do not have children or only have a toddler. However, the block is generally inhabited by more than three people in one sarusun unit, making it less ideal because of the increase in belongings. This has an impact on the way residents arrange the space in the sarusun unit for storage and places to rest (sleep); one solution is to use the space outside the unit, which is the corridor. Likewise, couples who have children in junior high school or above feel there is no privacy, either for children to study or play, or for parents, who experience problems with their romantic life and sexual relationships.

Considering that the corridor is open territory, residents occupy the area located in front of their sarusun unit according to the width of the unit. From the observations, data on the territorial mastery in block Seruni 5 generally ranged from $0.51 \mathrm{~m}^{2}$ to $1.00 \mathrm{~m}^{2}$ in the corridor, and from 1.51-2.00 $\mathrm{m}^{2}$ in the plant area, but all of this was highly dependent on the behavior and perception of the ownership limits of each occupant and was subjective. In general, residents occupied an additional area in the corridor of 0.51-3.00 $\mathrm{m}^{2}$, resulting in the corridor phenomenon.

Although the territorial mastery of the corridor was felt to be disturbing to other residents, because of the sense of tolerance of the occupants and considering that all the residents also do the same thing, it is tolerated if it does not disturb people passing. In general, residents are forced to accept the situation and are grateful for what they have, so they feel happy and comfortable, and feel at home in the block. For some residents, it is considered a characteristic of living in a rusunawa. This can be seen from the length of occupancy, which on average is over five years, and even as long as 16 years, ever since the establishment of the Rusunawa Bumi Cengkareng Indah. Some residents who already have homes in other places still live in Seruni 5, and finally, resell the purchased house.

From the description above, the territory is related to the situation and time/length of stay and causes a territorial shift due to the perception of each occupant of the control of the semi-public corridor area (joint ownership), to private.

\subsection{Territory as a Tangible Concept}

For some residents in block Seruni 5, territory as a tangible concept is understood as physical, real, and able to be felt by other occupants, in the form of the corridor as a type of terrace, with ownership limits of the sarusun unit, making a fence on a corridor in a corner of a building as a one-stop concept. However, for most residents there is no limit to the use of the corridor as a terrace concept, because of its function as a place to put things, for ngerumpi (chatting), nongkrong-nongkrong (hanging out), ngeriung (gathering together) and to practice hobbies.

The end part of the corridor has a fence with a lock, reinforcing the existence of physical territory and control upon the territory for personal gain. This resulted in protests from several residents because it disrupted the daily activities of some of them and blocked the fire evacuation route, so a joint agreement was made, the gate was unlocked, and other residents were free to enter and exit.

Page 6/20 
Chatting, hanging out, and gathering together are the daily activities of block Seruni 5 residents, especially mothers while watching their children playing in the corridor and chatting with other residents. One of the men's hobbies is raising animals (in general, birds in cages) and these are kept in the corridor.

All along the corridor in front of the building a plant area was created to grow plants that could absorb toxins and to act as air purifiers from pollution, a kind of sansevierias, which was a donation from Mr. Heru, one of the residents of block Seruni 5, who asked all the residents to look after the plants. But as time went by, although some residents liked to take care of the plants, others do not like to do so or did not have the time, so some were replaced by other types of plant or left to die, which eventually led to the area becoming a place for belongings, shoes, toys, etc.

The role of the corridor is very essential in accommodating the daily activities of the residents. It shapes the inhabitants' understanding of territory in simple language, namely as a place for chatting, so that almost every unit has a seat for this, or hanging out and gathering together, receiving guests and socializing, as well as being a place to keep belongings because the units are narrow. The concept of gathering together forms an imaginary and temporary space territory so that when the activity ends, the territory is lost without a trace or becomes temporary territory (Territory without Limits): where two or more people engage in activities of chatting/gathering together, then in that place an understanding of boundless territory begins to form in a certain period. (see Illustration Figure 8).

Location or place influences perceptions of territorial understanding, so the concept of the terrace is an essential part of the culture of living in block Seruni 5, from practicing hobbies to keeping animals and plants, drying clothes, storing belongings, chatting, hanging out, gathering together, family events, receiving guests and socializing (territory as a terrace concept, gathering together and hobbies), so the concept of temporary or non-permanent territory is formed.

The corridor as a connector between the many units of the sarusun plays an essential role in the apartment building, giving it the impression of being a large residential house with many rooms. The residents who live in it feel like an extended family living together under one roof for a certain period (living together in one place).

The concept of one building or one roof is a rationale for residents to understand territory as a large family without restrictions on private ownership, therefore preserving harmony and good relationships between the residents. The concept of a one roof territory and one large family is a mutual territorial understanding (collective) from the inhabitants of block Seruni 5 (territory as one roof and extended family).

\subsection{Territory as an Intangible Concept}

In addition to the territory being a tangible concept, it is also understood as a non-physical intangible one, which is not real but can be a sign, symbol, or atmosphere that is felt by the residents based on prevailing social norms. It is also shown in the form of the corridor as a sharing concept without any individual boundaries, and of the building, as a concept of attachment in a big family, which is a basic concept of the formation of territory (from the intangible to the tangible), as well as a characteristic of territorial understanding of the inhabitants of block Seruni 5. Territories for the residents are not determined by tangible boundaries but are understood more as an intangible action; for example, in terms of keeping things in the corridor, and sharing facilities as one big family who is Being close-knit.

The role of the corridor as a terrace for chatting, gathering together, practicing hobbies, and sharing space under one roof like an extended family has created a sense of togetherness and kinship created the role of the corridor with unlimited ownership of individuals, making the residents feel at home as if living in their hometown.

This can be seen in the sweeping and mopping of the corridor; in general, residents do it without considering ownership of it. Anyone who sweeps does it from the corner to the other side, as well as the mopping, which can be done alternately. Other aspects are shown by the free use of items, especially chairs for chatting or receiving guests, the storing of belongings, or hanging out in front of other units of the sarusun'(see Figure 9: 3-5). It is even shown in the use of bathrooms and prayer rooms in the sarusun unit for neighbors' purposes, and by the children who are free to play from door to door of other units (see Figure 9: 1,2).

Page $7 / 20$ 
When guests arrive, residents do not hesitate to use seats in the neighboring corridor without first having to get permission, so that the conversation becomes more comfortable, and sometimes the chairs in the corridor change places because other residents use them freely. Previously, the chief of the neighborhood (Rukun Tetangga/RT) provided one of his sarusun units, which was prepared as a living room and could be used by anyone to receive guests, as an expression of caring and of togetherness in sharing space, given the cramped space of the units with no living room. However, after his son grew up, the living room was made into the child's room.

When there is a family event, residents use their own corridor space as well as that of neighbors for food preparation (see Figure 10) and as a place to hold the event. Items in the corridor from the other sarusun units are temporarily moved to the corner to accommodate the activities and so as not to interfere with the course of the proceedings. After the event, everything is replaced as before. The other residents also helped run the event. This is done because the occupants have common interests and feel strong family ties (being close-knit).

The tendency not to distinguish between private and semi-private or semi-public territories for the residents of block Seruni 5 is shown by the concept of sharing under one roof as a large family, in the form of the use of bathrooms and prayer rooms for all the residents, thus creating shared territory (territory as togetherness), with no contested territories. Territories are understood not as a limitation, but as a mutually agreed condition (deliberation) for a better life and the sake of social harmonization (territory as harmony). Therefore, the understanding of the territory as an intangible concept can be concluded to be a concept of territory without any boundaries of individual ownership (borderless territory; see Figure 11).

The concept of sharing amongst the residents of block Seruni 5 makes relationships close, meaning that the residents care for each other and that territorial understanding is no longer something individual, but is the collective territory, with the concept of sharing in a large family (territory as a shared concept in an extended family). The sarusun units within block Seruni 5 are not interpreted as separate residential units (individual families) but are likened to a large house accommodating a large family, with rooms filled with siblings and with the head of the neighborhood the head of the household.

Therefore, territorial understanding of the boundaries of the area controlled is lost (transcending personal territory by sharing facilities, such as prayer rooms and bathrooms, with a corridor in front of the sarusun units), for the sake of living together in one place, creating the culture of living in block Seruni 5 (see illustration in Figure 12). Territories are no longer understood as ownership boundaries that need to be kept and maintained individually, but rather as a form of territorial togetherness for living under one roof and which are guarded together.

The residents generally feel at home in block Seruni 5 , because they experience good relationships, are familiar with their fellow residents, and have mutual respect and mutual understanding, so that togetherness, harmony, and being close-knit are created like one big family, unlike in other blocks. This can be seen from the length of stay in the block; although it feels cramped, there is a lack of privacy, and even though some residents have their own home in another place, they return there and are grateful for what they have.

These conditions and atmosphere create an emotional connection between the residents and the place, giving rise to territorial understanding based on attachment to the block, environment, and atmosphere. The attachment to the conditions, atmosphere, and place of residence (place attachment) for daily activities can lead to emotional, behavioral, and action bonds between the occupants and the place, which can have positive consequences that can foster prosperity, satisfaction, security, a sense of ownership and of arranging a place together, strong family ties, participation in the environment, and the formation of identity, both individually and in groups.

The corridor is the concept of the tenants' attachment to the atmosphere and place (as a terrace) on the same floor, as well as on different floors of the block Seruni 5 building, because the residents prefer activities in the corridor, like watching TV, sitting around, playing, studying, chatting, and holding thanksgiving events. This is the reason why residents feel at home and stay for a long time (living together in one place). The duration of their stay (time) influences the territorial understanding and shows attachment to the territory of togetherness. The concept of territorial attachment is an attachment to the place, both the corner position and the angle position, and block Seruni 5, so that the residents feel at home and stay for an extended period (territory as living together in one 
place). The concept of sharing, attachment, togetherness, and mutual understanding, and mutual respect amongst the inhabitants of block Seruni 5 can eliminate territorial boundaries and maintain harmony in the living culture, known as being close-knit.

The feeling of being close-knit that is shared by all the inhabitants of block Seruni 5 is shown in the will to live together in one place; for example, by the habit of gathering together on the terrace of the sarusun units (the corridor), or togetherness in undertaking voluntary work activities to repair parts of the building or maintenance of the upper water tanks. Without being asked, residents will join to assist, either in the form of work, materials, food, or donations. Being close-knit reflects living together in diversity, mutual respect, mutual understanding, mutual help, and care among fellow residents, so that they become familiar, feel grateful, and feel at home and want to stay for a long time, leading to attachments like relatives who live in harmony in their hometown under one roof as one large family (extended family). The concept of territoriality is an understanding of the concept of togetherness and family, mutual understanding and mutual respect, because of living in one building, under one roof for a certain period as a large family (territory as being close-knit culture).

\subsection{New Theory of Understanding of the Residential Territory}

With the feeling of living together in a rusunawa, accepting what people are, being grateful for being alive, and together looking for solutions to problems faced, especially the need for space with the increase in the number of residents, the number of belongings, and inadequate space, the residents do not mind putting belongings in the corridor (the territorial mastery phenomenon), as long as this does not disturb the circulation (semi-public territory), holding to the principle of community norms (for example, mutual respect, understanding, tolerance, kinship, and togetherness) known as being close-knit. Residents' understanding of territory based on; (1) elements and forms of territorial mastery; (2) the factors that influence it; (3) attitudes; (4) tolerance limits and agreements among residents; which is a new theory, namely the characteristics of understanding of hard and soft territory.

\subsection{Hard Territory}

Based on the understanding of several residents of; (1) the limit of mastery of in front of the 'sarusun' unit; even though it is not physical (intangible), its existence is recognized by other residents; (2) mastering the corner hall by installing a fence and lock (tangible); (3) tangible understanding as a collective territory by making a gate on the ground floor; so that in this research can be interpreted as a characteristic of understanding the territory, because it is explicit, clear, acknowledged and maintained.

The different colors of the walls and the sizes and patterns of the ceramics can function as clear territorial markers. Areas for plants that are maintained or used for other purposes, such as places for belongings, shoes/sandals, etc. and which are generally limited to the width of each unit and used for placement of items along each of the sarusun units, can also be interpreted as the understanding of hard territory.

\subsection{Soft Territory}

Social relations that take place between the residents in the block Seruni 5 community are excellent and close; they greet each other, get to know each other, and respect and understand each other (intangible). Eliminating ownership boundaries known as private territory, even in some cases on a micro-scale, such as when neighbors need space for prayer or bathing, they can use others' units (private territory). Likewise, the corridor (semi-public territory) is used to keep items and for guests to sleep (private territory). Territorial shifts occur interpreted as characteristics of the understanding of soft territory because it is flexible. Flexible means; (1) temporary territory; (2) can appear or disappear; (3) can expand or decrease according to needs and agreements; (5) full of compromises that can be accepted up to a precise tolerance threshold, for the sake of togetherness and harmonization of relationships; thus, enabling the occurrence of territorial shifts (exceeding individual territorial limits).

The territories that exist in Seruni 5 are borderless, formed or related to the situation (situational) and time (length of stay), as well as to the absence of contested territory, and can be compromised (compromised territory) as needed. The difference from the theory which states that when territories have not been formed, or are still subject to struggle, aggression is common. 
No restrictions are imposed to indicate the areas of ownership, so the result is togetherness in the community, sharing, mutual understanding, high tolerance, and being close-knit (intangibles) because the residents feel that they live under one roof in one building and have a feeling of being together (collectively), along with the role of the neighborhood chief in preserving social harmony. The territory is a concept of preserving togetherness and harmony, known as being close-knit, and which can be interpreted as a characteristic of the understanding of soft territory.

Territory in the concept of being close-knit comprises values in the form of principles of; (1) mutual respect; (2) helping; (3) sharing; (4) and giving of responsible freedom (self-awareness with a certain degree of tolerance, such as not disturbing circulation, hobbies that well cared for and not disturbing other residents), (5) maintain social intimacy and harmony; (6) provide a sense of security, comfort, gratitude; (7) enjoyment of living together; (8) create a spirit of togetherness in the territory; without exceeding the limits of individual ownership as a social basis of territorial understanding. Therefore, classification of the occupants' interpretation of the territory is divided into three parts; (1) private territory; (2) shared territory (soft territory), namely territory without semi-private or semi-public boundaries, with a territorial understanding of being close-knit as the unifier; and (3) public territory.

Based on the understanding of the being close-knit concept of territory, the understanding of territory of the inhabitants of Seruni 5 is not an individual territory, but territory without individual borders, with being close-knit (see Figure 13) as a basic concept of territorial understanding (territory as a being close-knit culture), which was born and developed naturally by the residents over a certain period and has become a social norm (community norm) in block Seruni 5, Rusunawa Bumi Cengkareng Indah, DKI Jakarta.

In their development, the characteristics of the understanding of hard territory can change into the characteristics of understanding the soft territory, or vice versa. In block Seruni 5 , the characteristics of the understanding hard territory generally change and experience a shift towards those of understanding soft territory, with a certain tolerance threshold (see illustration in Figure 14), including:

The understanding of some residents of the limits of corridor mastery is based on the width of the sarusun unit. In several interviews they explained the free use of the corridor to receive guests, for gathering together, the use of chairs or children's toys, to practice hobbies and keep animals and plants, and to keep belongings without boundaries; for example, by sweeping and mopping not just the corridor in front of the sarusun unit, but also from one end to the other.

Territorial mastery of the corner hall by making a fence and lock (tangible), so families were no longer locked in and other occupants could freely enter and exit.

The color of the walls and doors of the sarusun unit; the color, size, and pattern of the corridor ceramics; hobbies and caring for animals and plants; and keeping items in front of each unit are not interpreted as a territorial marker, but only as identity.

The understanding of territory of the residents because of the phenomenon of territorial mastery in block Seruni 5 , is better understood as a characteristic of understanding soft territory, with a certain tolerance threshold, and agreement based on understanding the concept of territoriality under one roof as a large family (extended family), so territory (soft territory) can eliminate differences in religion, ethnicity, race, and other interests, and transcend individual territorial boundaries (interests and ownership) to create a harmonious environment in the community.

\section{Conclusion}

The results of the research analysis on understanding the occupants of territory using the GT research method in block Seruni 5 , helped develop a new theory with a common grounding basis, and which was a manifestation of the substantive characteristics of territorial understanding, namely; (1) Characteristics of Understanding Hard Territory: The characteristics of understanding hard territory are territorial mastery that is tangible or intangible, fixed or unchanged, firm, and whose existence in space is clear and can be seen, owned, or controlled and maintained by other residents; (2) Characteristics of Understanding Soft Territory: The characteristics of understanding soft territory are territory that is tangible and intangible, allowing for a shift in the territory (beyond individual territory) and flexibility; it may change (melt) or not be fixed; appear or disappear (temporary territory); expand or decrease according to the needs and agreements that are not formal (being close-knit), and is soft because it is an expression of family emotion that is culturally called being close-knit. Therefore, mastery of the soft territory occurs not only because of tolerance but 
rather because it prioritizes a sense of kinship for the sake of being together under one roof (i.e., rusuna) and harmonizes the relationship between people living in a community.

\section{Declarations}

\section{Acknowledgments}

Thanks to the chief of a neighborhood (Rukun Tetangga/'RT') and the residents of block Seruni 5, Rusunawa Bumi Cengkareng Indah, Jakarta, who had time for accompanying our discussion, and gave great input to our research

\section{References}

Altman, I., 1975. Environment and Social Behavior: Privacy, Personal Space, Territory and Crowding. Monterey: Brooks Cole.

Aurora, S., 2014. Territory and Subjectivity: The Philosophical Nomadism of Deleuze and Canetti. Minerva - An Open Access Journal of Philosophy, Volume 18, pp. 1-26.

Aziz, A. A. \& Ahmad, A. S., 2009. Home Making in Low-Cost Housing Area. Selangor, Faculty of Architecture, Planning \& Surveying, Universiti Teknologi MARA, Shah Alam, Selangor, Malaysia.

Bahri, S., 2005. Rumah Susun Sebagai Bentuk Budaya Bermukim Masyarakat Modern. Jurnal Sistem Teknik Industri, July, 6(3), pp. 97-102.

Burhanuddin, 2010. Karakteristik Teritorialitas Ruang Pada Permukiman Padat Di Kampung Klitren Lor Kecamatan Gondokusuman, Yogyakarta. Jurnal "Ruang", Maret.2(1).

Castillo, G. A., 2018. Qualitative Methodologies: Which is the best approach for your Dissertation topic?. International Journal of Novel Research in Education and Learning, 5(2), pp. 83-90.

Charmaz, K., 2006. Constructing Grounded Theory: A Practical Guide Through Qualitative Analysis. London: Sage Publications. http://www.sxf.uevora.pt/wp-content/uploads/2013/03/Charmaz_2006.pdf.

Creswell, J. W., 1998. Qualitative Inquiry and Research Design: Choosing Among Five Traditions. Thousand Oaks, California-USA: Sage Publication.

Daymond, C. \& Holloway, l., 2008. Metode-metode Riset dalam Public Relations dan Marketing Communications. Yogyakarta: Bentang.

Fatimah, D., 2010/2011. Gender Dalam Teritori. Jurnal Waca Cipta Ruang, II(II).

Glaser, B. G., 1994. More Grounded Theory Methodology: A Reader. Mill Valley: CA: Sociology Press. ISBN 1-884156-07-X. http://www.sociologypress.com/books/readers/more_grounded_theory_methodology.htm.

Glaser, B. G. \& Strauss, A. L., 1967. The Discovery of Grounded Theory: Strategies for Qualitative Research. Chicago: Aldine Publishing Company.

Goulding, C., 2002. Grounded Theory: A Practical Guide for Management, Business, and Market Researchers. London: SAGE Publications Ltd. https://www.amazon.com/Grounded-Theory-Practical-Management-Researchers/dp/0761966838. DOI: 10.7748/nr.11.1.81.s11.

Haryadi \& Setiawan, B., 2010. Arsitektur Lingkungan dan Perilaku. Yogyakarta: Gadjah Mada University Press. 
Heidegger, M., 1971. Building Dwelling Thinking. In Poetry, Language, and Thought. (Originally "Bauen Wohnen Denken", in Vorträge und Aufsätze. Pfullingen: Neske, 1954). New York: Harper \& Row.

Holahan, C. J., 1982. Environmental Psychology. New York: Random House.

Kamil, R., 2015. Mengubah Dunia Bareng-Bareng. Bandung: Kaifa, PT. Mizan Pustaka.

Khan, S. N., 2014. Qualitative Research Method: Grounded Theory. International Journal of Business and Management, 9(11), pp. 224-233.

Kintrea, K., Bannister, J. \& Pickering, J., 2010. Territoriality and Disadvantage Among Young People: An Exploratory Study of Six British Neighbourhoods. @ Springer Science+Business Media B.V., J Hous and the Built Environ, Volume 25, p. 447-465.

Kurniadi, F., Pramitasari, D. \& Wijono, D., 2012. Konsep Perilaku Teritorialitas di Kawasan Pasar Sudirman Pontianak. Vokasi, October, 8(3), pp. 197-208.

Lianto, F., 2018. Teorisasi Fenomena Penguasaan Teritori Skala Meso di Blok Seruni 5, Rusunawa Bumi Cengkareng Indah, DKI Jakarta. Bandung: Universitas Katolik Parahyangan.

Lianto, F., 2019. Grounded Theory Methodology in Architectural Research. Journal of Physics: Conference Series, Volume 1179, p. 012102.

Lianto, F., Arifin, L. S. \& Dwisusanto, Y. B., 2017. ole of Corridor in Territorial Meaning Formation in "Owned Low-cost Apartments" ('Rusunami') Bidara Cina, Jakarta, Indonesia. International Journal on Advanced Science, Engineering and Information Technology, 7(2), pp. 399-405.

Lianto, F. \& Dwisusanto, Y. B., 2015. Teritorialitas dan Keamanan Penghuni Pada Permukiman Horisontal dan Vertikal (Rumah Susun Sederhana) (Studi Kasus: Rumah Susun Sederhana Sewa (Rusunawa) Bumi Cengkareng Indah, Jakarta ). Jurnal Sosek Pekerjaan Umum, November, 7(3), pp. 219 - 227.

Lyman, S. M. \& Scott, M. B., 1967. Territoriality: A Neglected Sociological Dimension. Social Problems, 15(2), pp. $236-249$.

Murti, F., 2012. Kajian Teritorialitas Pasar Dan Perilaku, Studi Kasus Pasar Genteng Baru Surabaya. Surabaya, Dies 45 Jurusan Arsitektur Universitas Kristen Petra, pp. 127-136.

Newman, O., 1972 b. Defensible Space: Crime Prevention Through Urban Design. New York: Macmillan.

Pryor, J., 2009. Opting in and opting out: a grounded theory of nursing's contribution to inpatient rehabilitation. Clinical Rehabilitation, Volume 23, pp. 1124-1135. http://citeseerx.ist.psu.edu/viewdoc/download?

doi=10.1.1.895.1639\&rep=rep1\&type=pdf.

Putri, R., Pangarsa, G. W. \& Ernawati, J., 2012. Fleksibilitas Ruang Dalam Tradisi Sinoman dan Biyada di Dusun Karang Ampel Malang Dengan Pendekatan Teritori. Surabaya, Dies 45 Jurusan Arsitektur Universitas Kristen Petra, pp. 195-204.

Salura, P., 2001. Ber-arsitektur; Membuat, Menggunakan, Mengalami dan Memahami Arsitektur. Bandung: Architecture \& Communication.

Samuel, A., 2011. “Grounding Rapidly Emerging Disciplines: The Fairtrade Towns Movement”, in: Researching Sustainability: A Guide to Social Science Method, Practice and Engagement. Earthscan, pp. 120-136.

https://www.researchgate.net/publication/317350690_Grounding_Rapidly_Emerging_Disciplines_The_Fairtrade_Towns_Movement.

Sari, A. A., 2013. Transformasi Spasial - Teritorial Kawasan Alun-Alun Malang: Sebuah Produk Budaya Akibat Perkembangan Jaman. e-Jurnal Eco-Teknologi UWIKA (eJETU), July, 1(1), pp. 13-21.

Sastrohutomo, S. A. \& Sudarma, E., 2007. Mekanisme Kontrol Teritorial Pada Perumahan Susun Sederhana (RSS); Penelusuran Potensi Pendekatan "Territoriality" Untuk Menjelaskan Gejala Perubahan Setting Fisik RSS oleh Penghuninya, Surabaya: Penelitian 
Fundamental Multi Years tahun I - 2007, 71 halaman, Institut Teknologi Sepuluh Nopember.

Schulz, C. N., 1988. Architecture; Meaning and Place. New York: Rizzoli.

Setyowati, 2010. Grounded Theory Sebagai Pilihan Metode Riset Kualitatif Keperawatan. Jurnal Keperawatan Indonesia, Juli, 13(2), pp. 119-123. https://media.neliti.com/media/publications/111355-ID-grounded-theory-sebagai-pilihan-metode-r.pdf.

Sommer, R., 1969. Personal Space: The Behavioral Basis of Design. Englewood Cliffs: Prentice-Hall.

Sommer, R. \& Becker, F. D., 1969. Territorial Defense and The Good Neighbor. Journal of Personality and Social Psychology, 11(2), pp. 85-92.

Soukotta, D., Waani, J. O. \& Rogi, O. H., 2014. Klasifikasi Ruang Teritori Publik Pada Rumah-Rumah Di Kampung Jawa Tondano, Studi Kasus Di Lingkungan III. Media Matrasain, August.11(2).

Strauss, A. \& Corbin, J., 1990. Basics of Qualitative Research: Grounded Theory Procedures and Techniques. London: Sage Publications Inc.

Strauss, A. \& Corbin, J., 2015. Basics of Qualitative Research: Techniques and Procedures for Developing Grounded Theory. Thousand Oaks, CA: Sage Publications Inc.

Supriyono, E. E. L., 2014. Teritori Ruang Publik Perkotaan, Studi Kasus Kota Semarang, Surakarta Dan Yogyakarta. s.l., FT UMS.

Yatmo, Y. A. \& Atmodiwirjo, P., 2013. Spatial Strategies for Domestic Service Activities in Urban Kampung Houses. International Journal of Technology, 4(1), pp. 24-33.

Zubaidi, F., Santosa, H. R. \& Faqih, M., 2013. Territoriality in The Traditional Settlement Context. Psychology and Behavioral Sciences, 2(3), pp. 89-95.

\section{Figures}
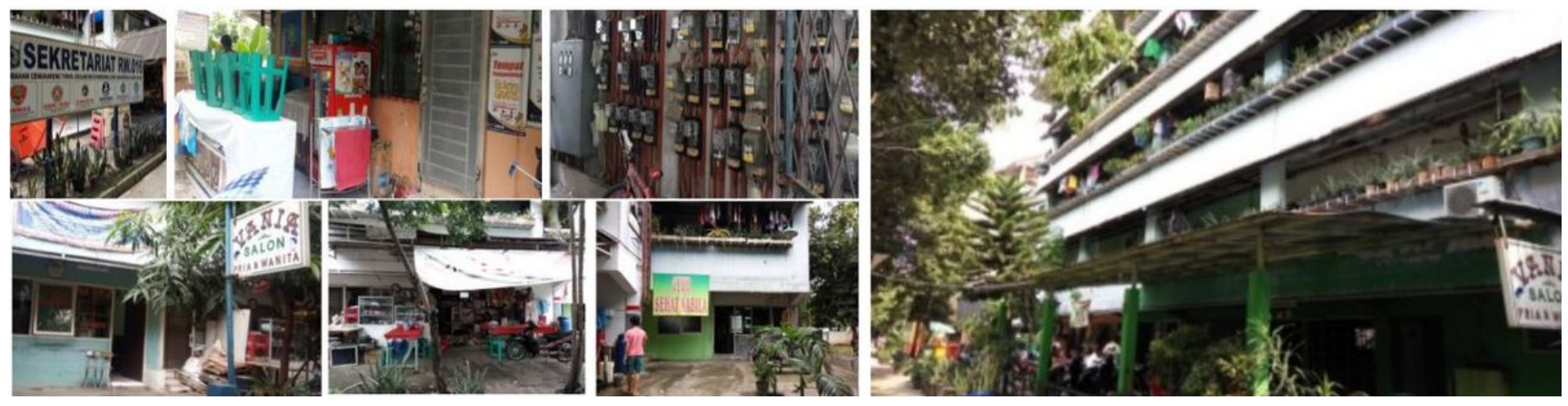

Figure 1

Block Seruni 5, Rusunawa Bumi Cengkareng Indah Source: Authors. 


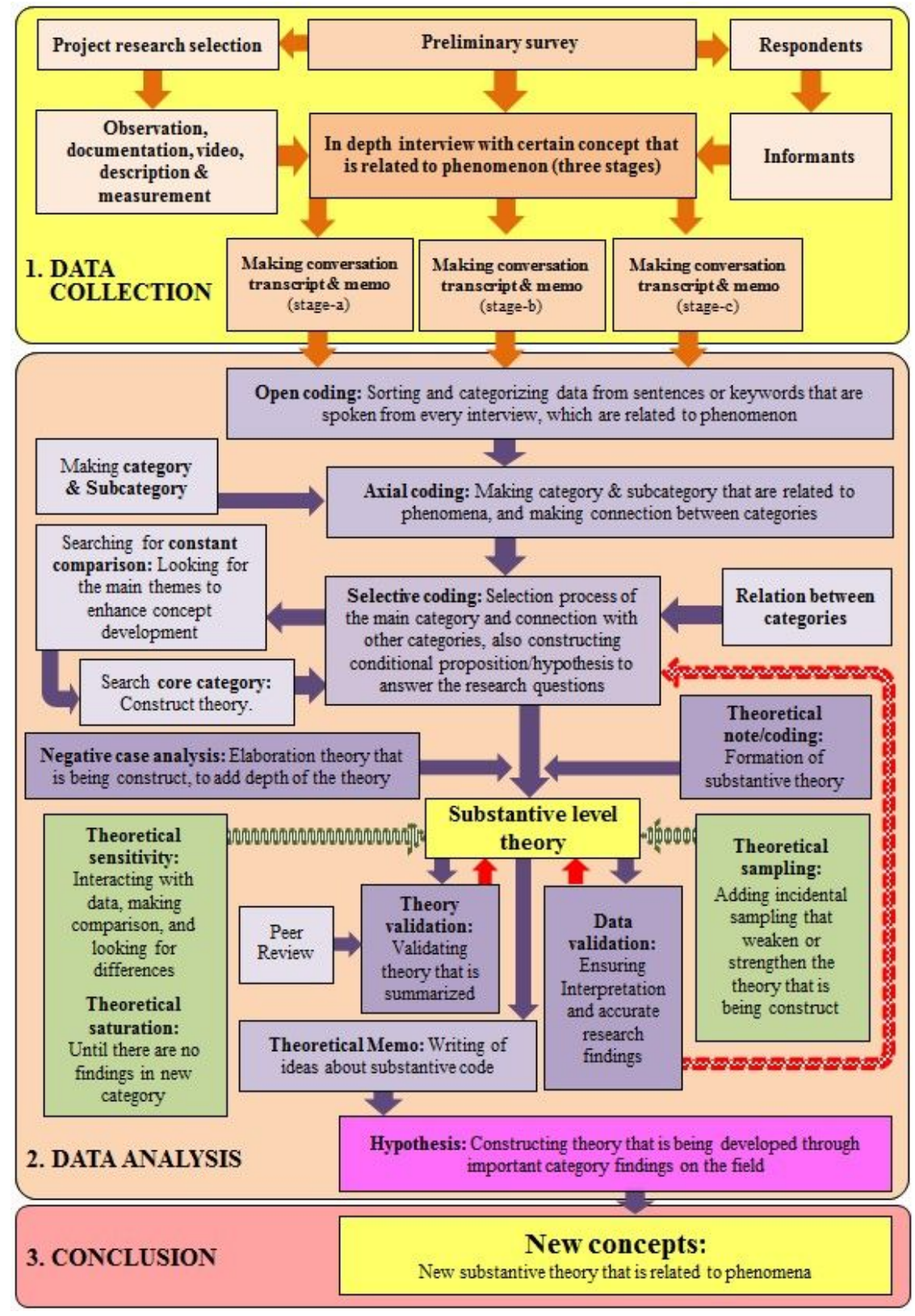

\section{Figure 2}

Diagram of Grounded Theory Methodology in Architectural Research Source: Grounded Theory Methodology in Architectural Research (Lianto, 2018; Lianto, 2019) 


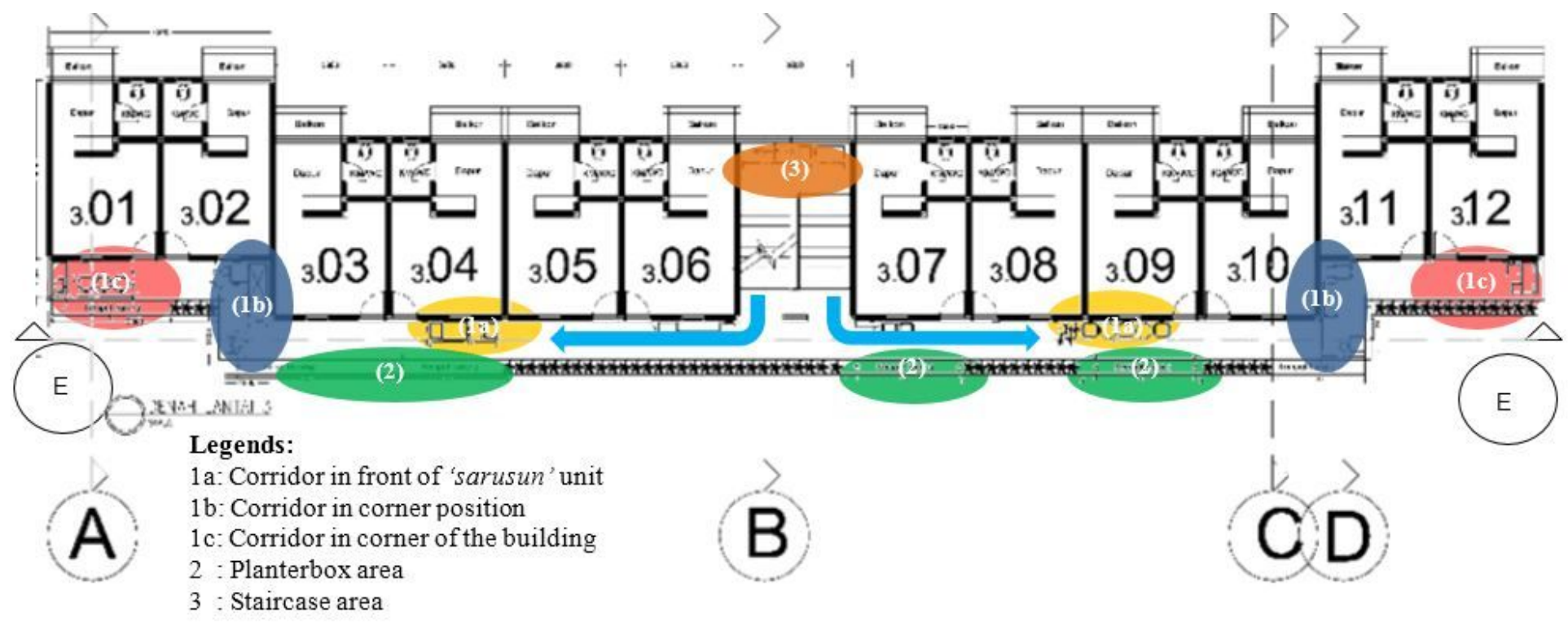

Figure 3

Territorial Mastery Source: Authors
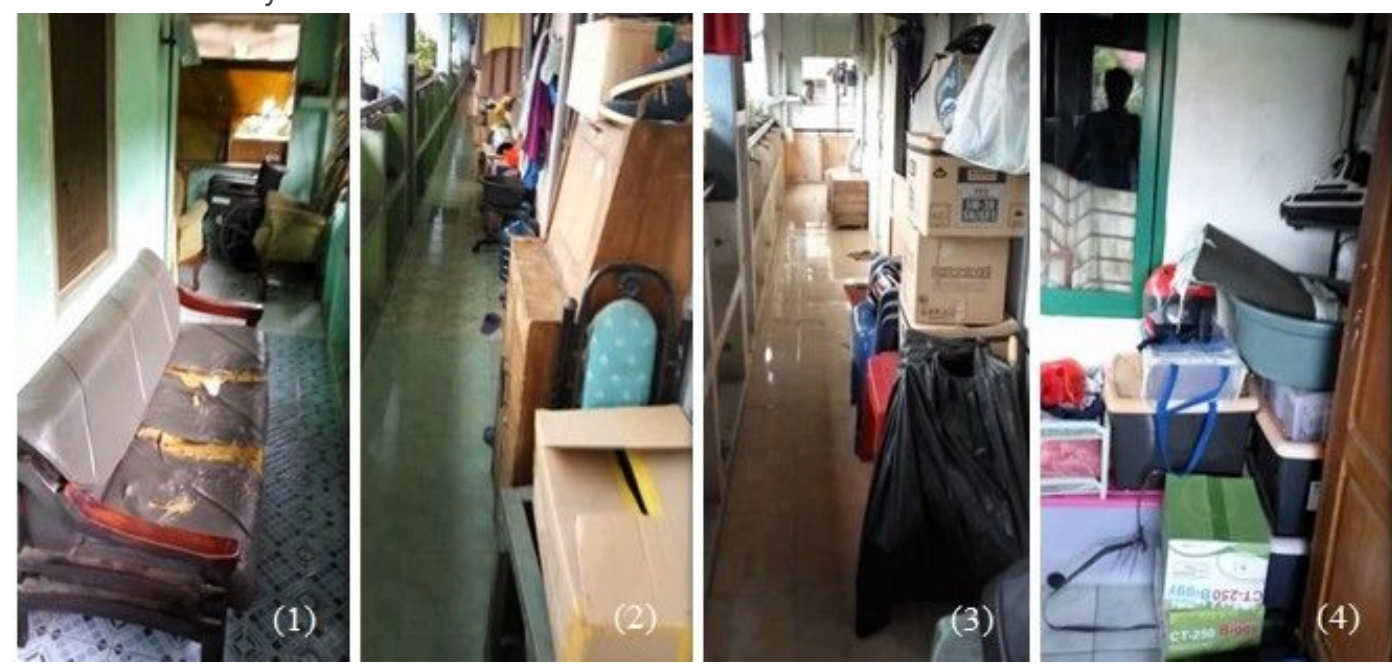

Figure 4

Corridor Area with Goods in Front of the Sarusun Unit Source: Authors
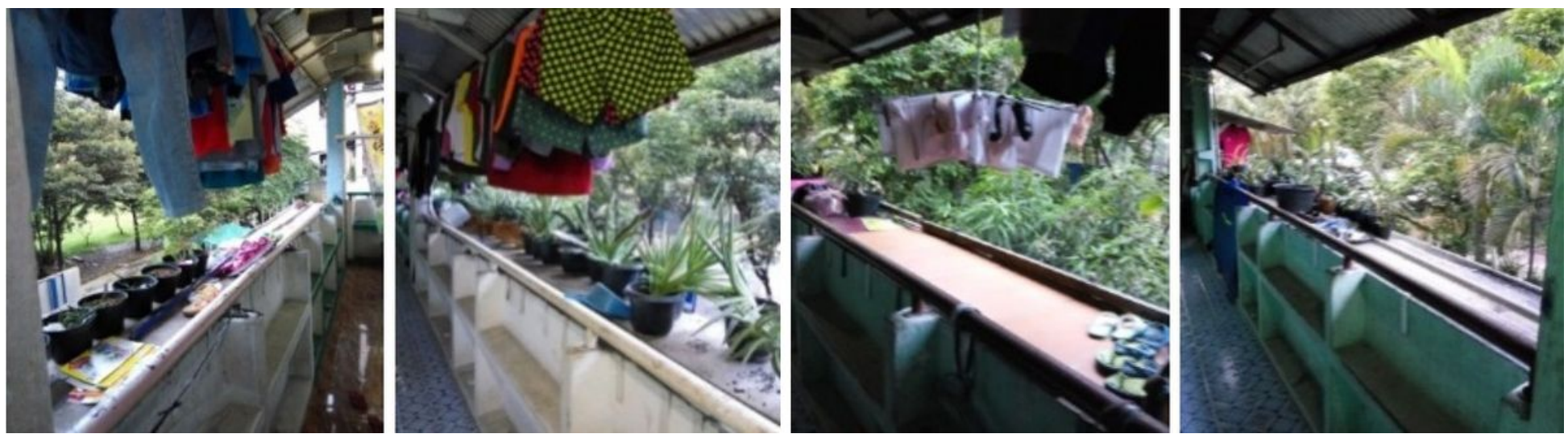

Figure 5

Planter box Area in Front of the Sarusun Unit Source: Authors 

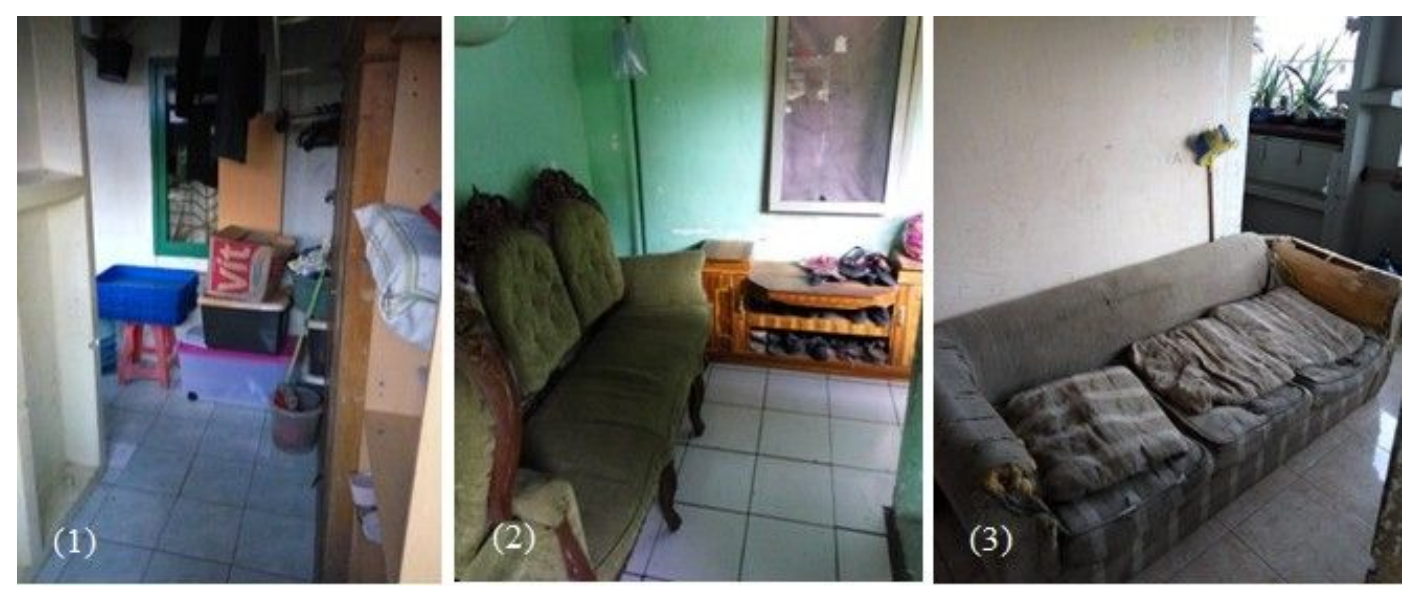

Figure 6

Corner of the Corridor Area Used as a Sitting Area and for Keeping Belongings Source: Authors
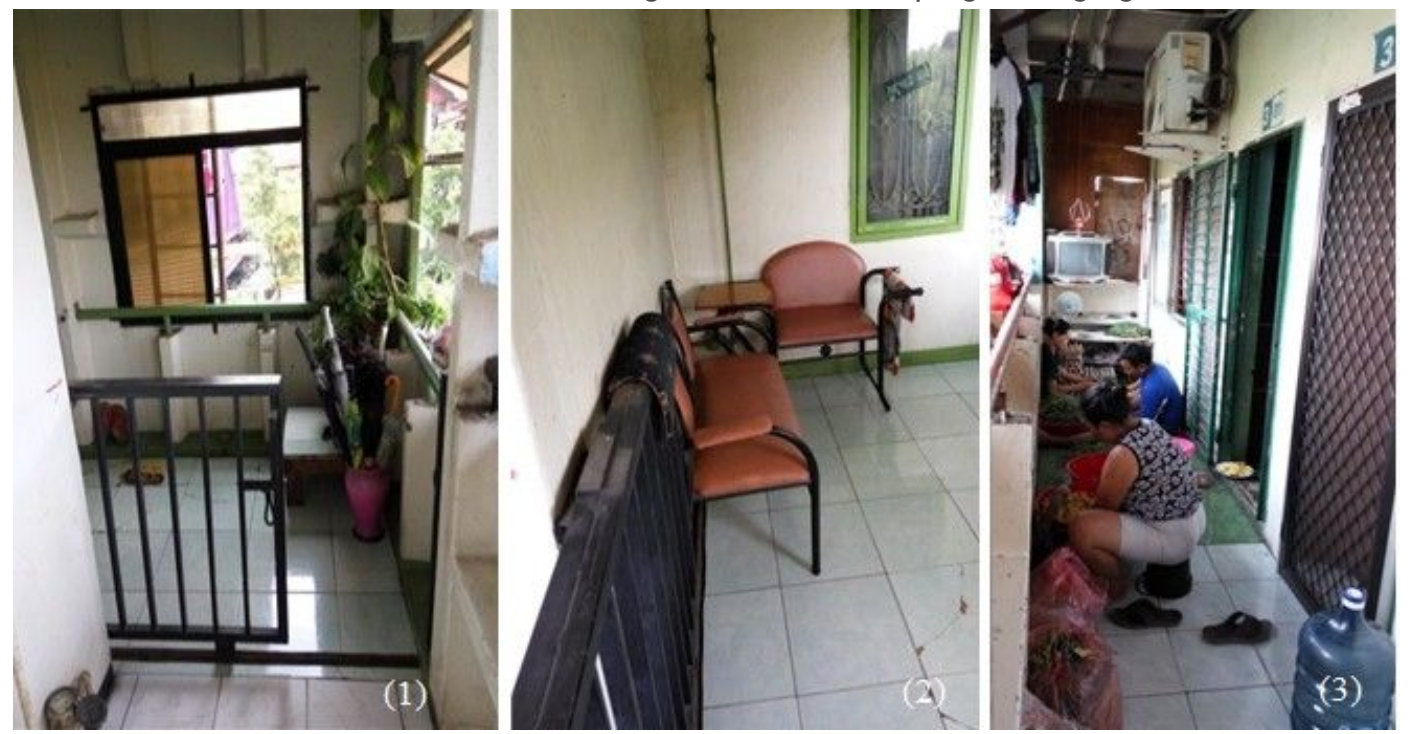

Figure 7

End of the Corridor Area (Corner of the Building) for Guest Room and Working Space Source: Authors
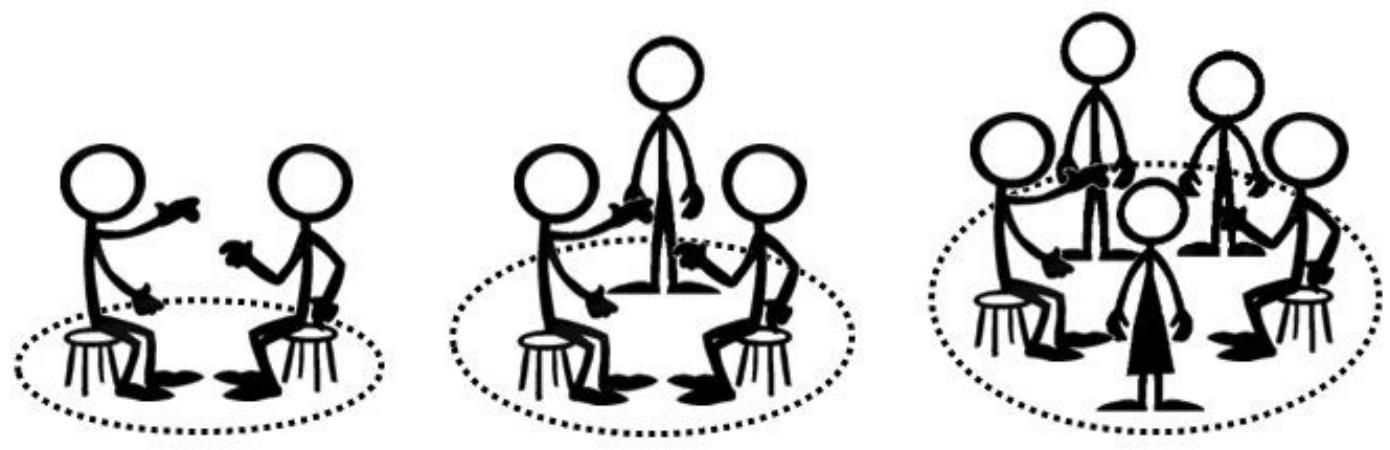

Figure 8

Illustration of the Formation of Gathering together, Territory without Limits Source: Authors 

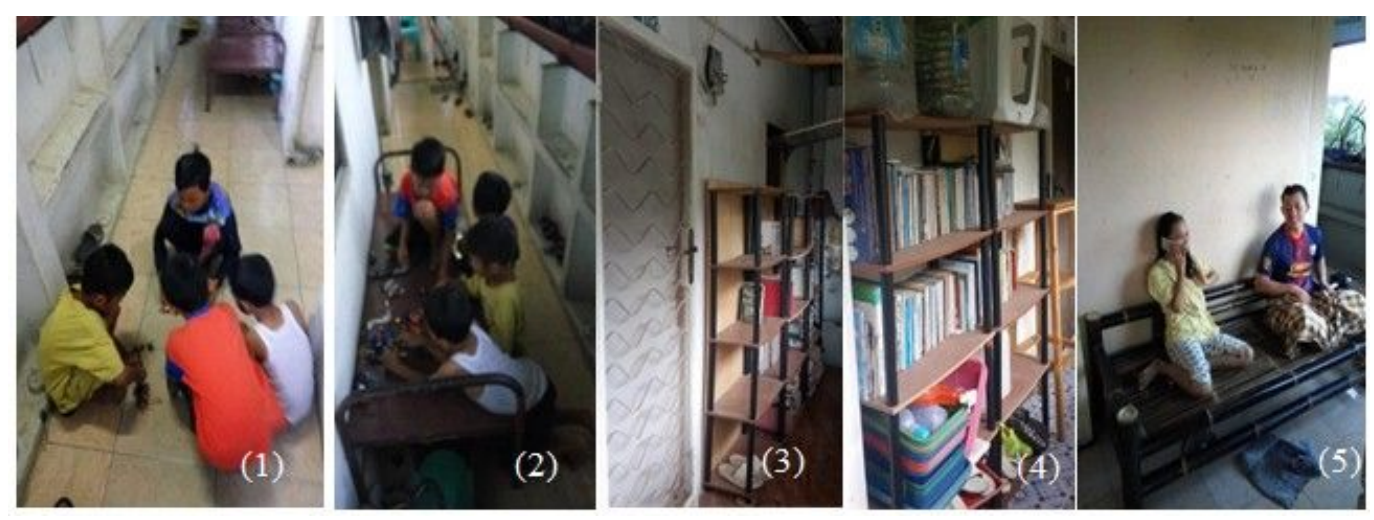

\section{Figure 9}

Use of Corridor and Belongings in Front of Other Occupants' Sarusun Units Source: Authors

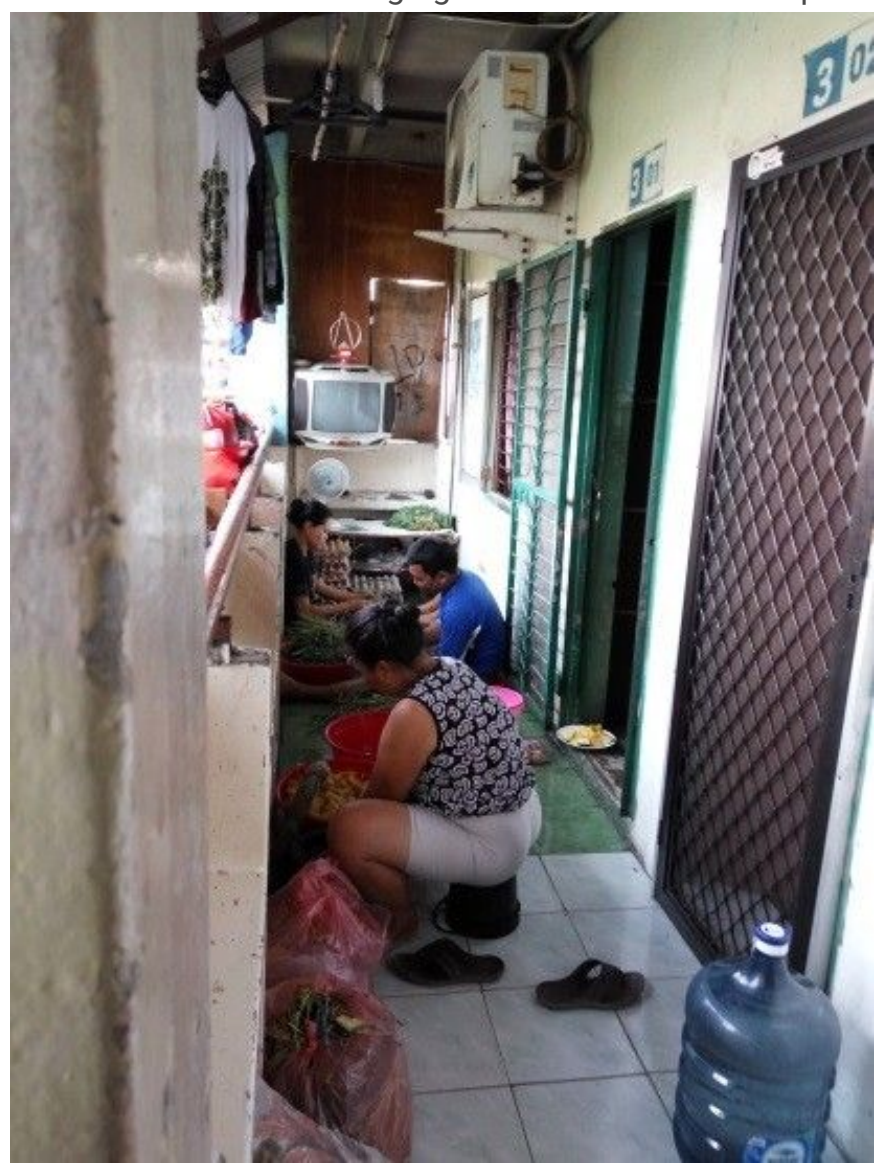

\section{Figure 10}

Use of the Corridor for Family Events in Front of Other Sarusun Units Source: Authors 


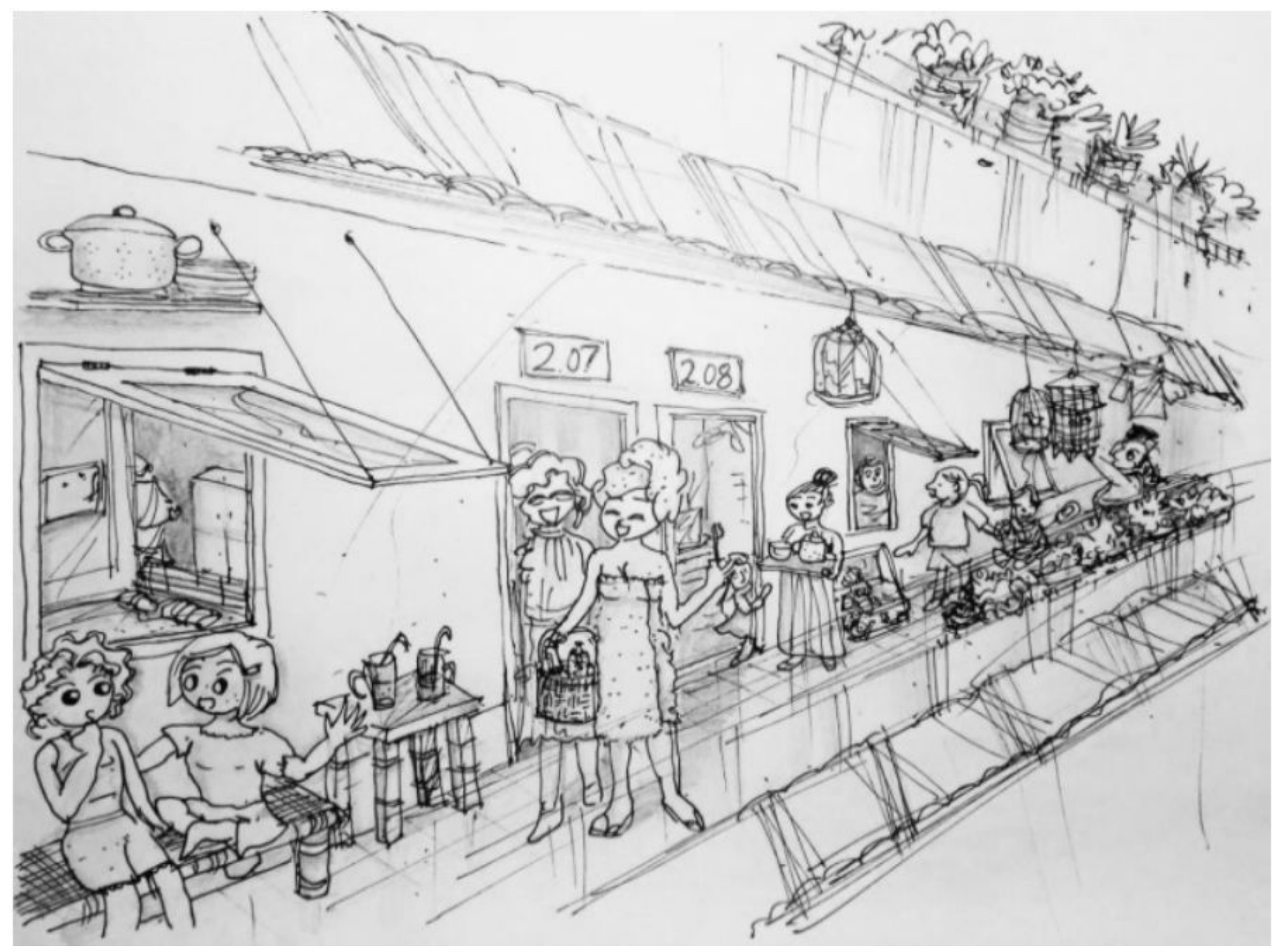

Figure 11

Illustration of Borderless Territory Source: Authors

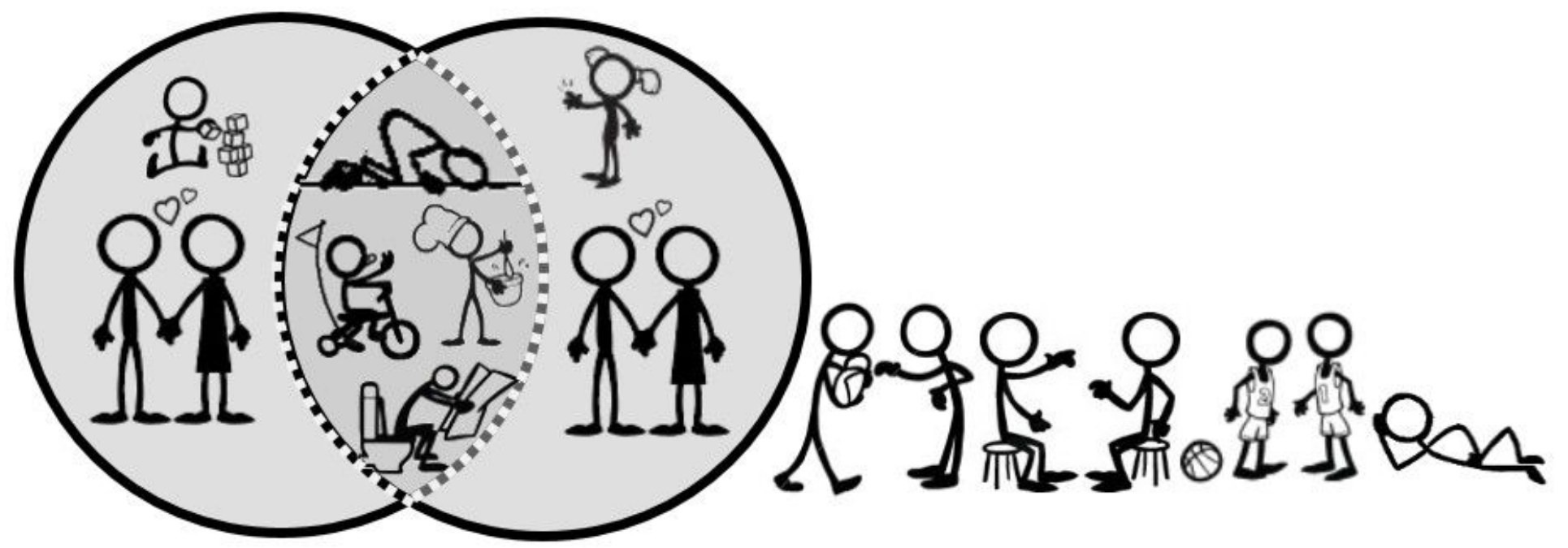

Figure 12

Illustration of Sharing Facilities Source: Authors 


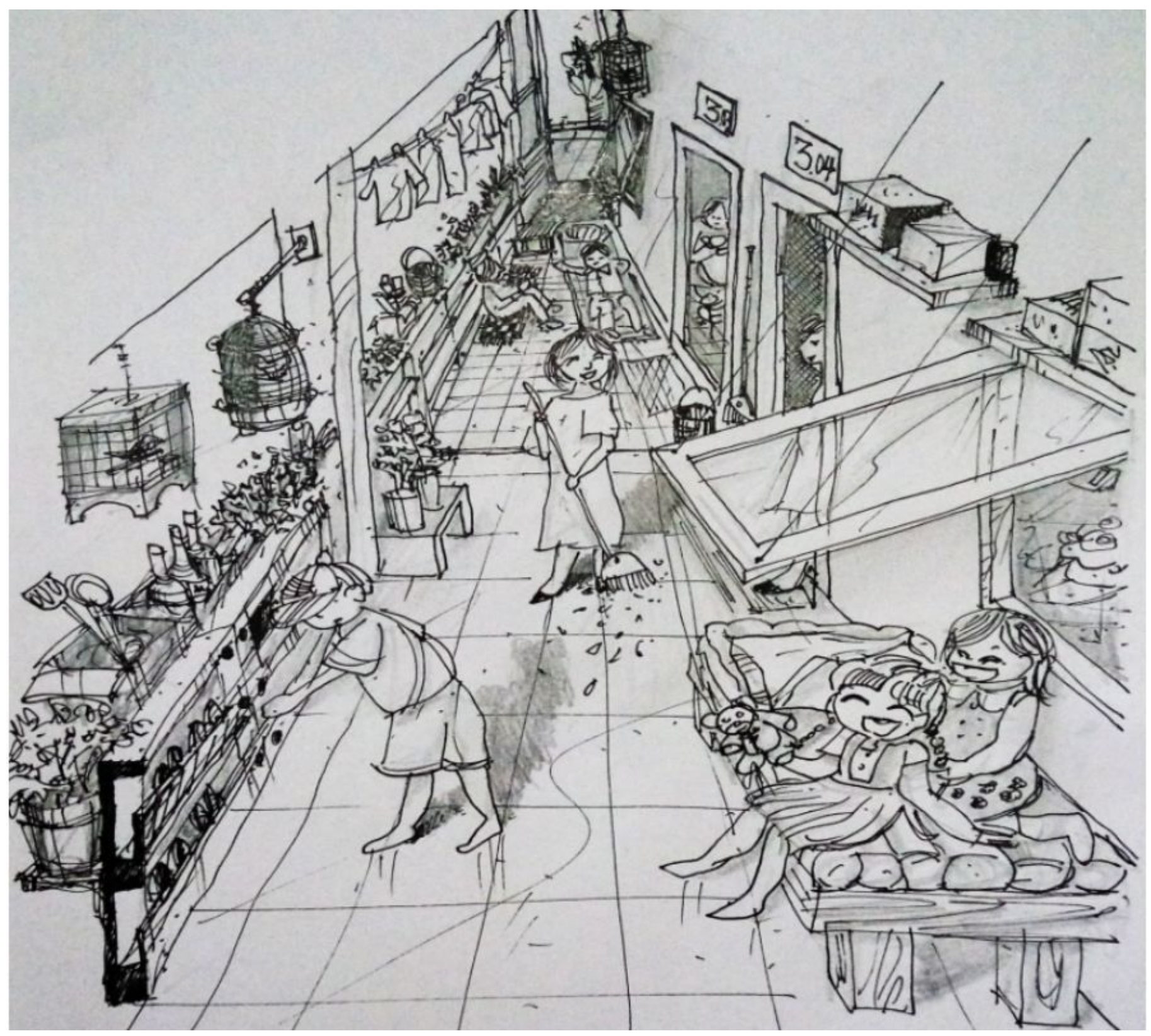

Figure 13

Illustration of Territory as Being close-knit Culture Source: Authors

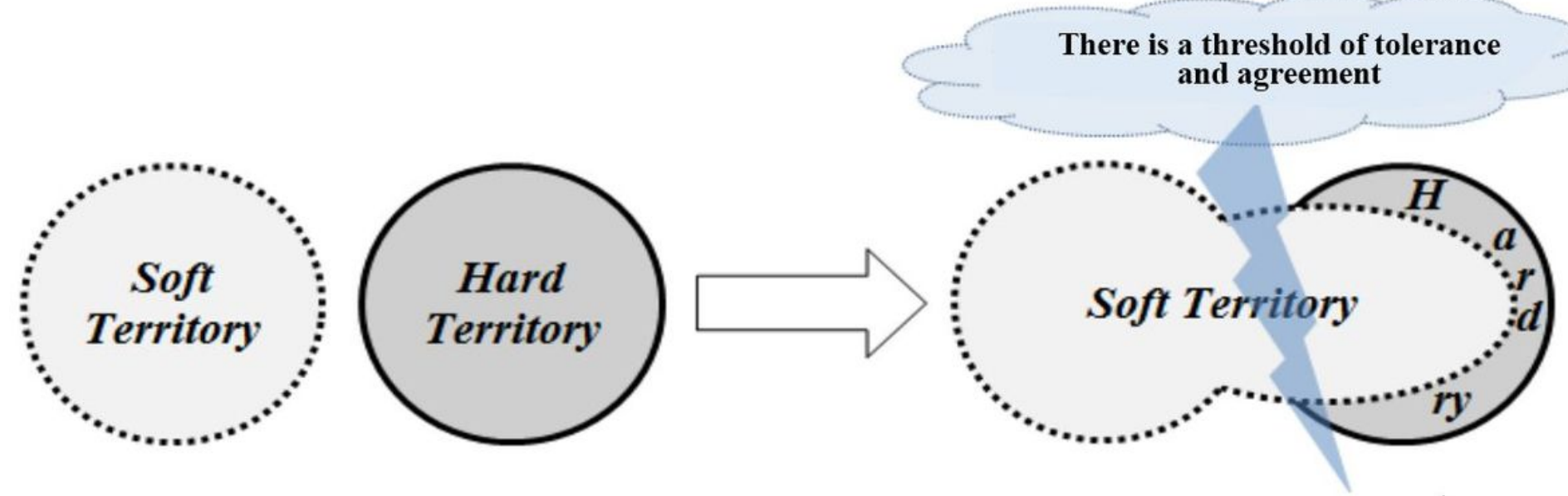




\section{Figure 14}

Illustration of the Shift in the Characteristics of Understanding Hard Territory and Soft Territory Source: Authors 